\title{
ANALYSIS OF CULTURAL MEANING'S COMPONENTS IN THE TRADITIONALLY POST-MARRIAGE CEREMONY OF THE BOLAANG MONGONDOW ETHNIC: ANTHRO-LINGUISTIC STUDIES
}

\author{
Femmy Lumempouw \\ Faculty of Humanities, Sam Ratulangi University Manado, North Sulawesi \\ DOI: 10.46609/IJSSER.2020.v05i11.021 URL: https://doi.org/10.46609/IJSSER.2020.v05i11.021
}

\section{ABSTRACT}

The study concerning on analysis of cultural meaning's components in the traditionally postmarriage ceremony of the Bolaang Mongondow ethnic is aimed to (1) identify and classify traditionally post-marriage ceremony of the Bolaang Mongondow ethnic; (2) recognize and categorize a unit of language, such as proverbs, prays, verses, word forms, phrases, clauses/sentences, discourses, and idioms, using during traditionally post-marriage ceremony of the Bolaang Mongondow ethnic; and (3) explain cultural meaning's components, as contained in verses, such as phrases, clauses/sentences, and idioms, during traditionally post-marriage ceremony in the Bolaang Mongondow ethnic. In this research, qualitative-descriptive method was employed. While, the data was analyzed in two steps, consisting of (1) analysis of language unit concept, and (2) analysis of anthro-linguistic.

As a result, this research finds out that there were 13 steps during the traditionally post-marriage ceremony of the Bolaang Mongondow ethnic. Those steps were (1) gama 'mengambil' (taking out) bride heading into groom's house; (2) polampangon kun tutugun lanang 'melangkah di depan pengantin wanita' (stepping in front of bride); (3) pololanon kon tubig 'melewati air' (passing through water); (4) poponikon kontukad 'menaiki tangga' (going up stairs); (5) kungkum in pawung 'payung' (umbrella); (6) pilat in siripu 'lepas alas kaki' (taking off shoes/sandals); (7) polampa kon tonom 'melangkah di pintu utama' (stepping in the main door); (8) pokilituan 'menyilakan duduk' (inviting to sit); (9) pogapangan 'duduk berdampingan' (siting side by side); (10) buka in kokudu 'buka penutup wajah' (opening the face lid); (11) pokimamaan 'makan sirih dan pinang' (eating betel and areca nut); (12) pongiobawan 'silakan makan' (inviting to dine); and (13) polimumugan 'kumur-kumur' (gargle/rinsing the mouth).

Keywords: Cultural Meaning's Components, Traditionally Post-marriage, the Bolaang Mongondow Ethnic 
International Journal of Social Science and Economic Research

ISSN: 2455-8834

Volume:05, Issue:11 "November 2020"

\section{INTRODUCTION}

In the Province of North Sulawesi, there are primarily varied ethnics lived in some regions, such as Minahasa, Sangihe Island, Talaud Island, Sitaro Island, and Bolaang Mongondow. Particularly, Bolaang Mongondow, demographically, has enfolded into four districts, consisting of District of Bolaang Mongondow, District of Bolaang Mongondow Selatan, District of Bolaang Mongondow Utara, and District of Bolaang Mongondow Timur. It also has traditionally cultural arts circulating in its residents' life, which are dance, traditional games, culinary, fashion, traditional ceremony, and architecture. While, traditional ceremonies firmly held by the Bolaang Mongondow ethnic are marriage, newborn, death, harvest, new house construction, fish catchment, and evading evil deeds.

Specifically, in this research (2019), there are three objectives formulated, comprising of: (1) traditionally post-marriage process of the Bolaang Mongondow ethnic, (2) a unit of language such as proverbs, prays, and verses in the form of words, phrases, clauses/sentences, discourse, and culturally meaningful idioms, performed during traditionally post-marriage of the Bolaang Mongondow ethnic, and (3) cultural meaning contained within proverbs, prays, verses in the form of words, phrases, clauses/sentences, discourse, and idioms during traditionally postmarriage ceremony in the Bolaang Mongondow ethnic.

In doing so, literature reviews in this research are underlyingly stressed on anthro-linguistic approach reviewing on relation of language and socio-cultural aspects from language community. This concept refers to ethnicity of language community preserving itself and others' assumption, having similar natures of territorial, genealogy, language, religion, mode of living, mass organization, and politic. Such a group of ethnic, thus, commonly considers that they have collectively homogenous identity. It is usually signified by significant personal attachment, emotional embeddedness, moral commitment, social binding, and long-lasting companionship. Also, in anthro-linguistic, it denotes on language system as resources, social means, and act of speech purposively being its main element of analysis (Duranti in Djawanai, 2011).

According to Saussure (1988), meaning is definition or concept possessed on or located in linguistic sign. If identity of such linguistic sign is presumably homogenized with words or lexicons and morphemes, such meaning or concept is possessed in every morpheme. Djadjasudarma (1997), further, firmly sets out that learning a meaning, substantially, means learning how each language user within certain society mutually understands such language.

Additionally, D'Andarde (1984) differentiates four cultural meanings, namely first, meaning representing real world (representational). Based on this view, culture consists of knowledge and belief comprehending the world, or worldview, fundamentally relied on true-or-false proposition, 


\section{International Journal of Social Science and Economic Research}

ISSN: $2455-8834$

Volume:05, Issue:11 "November 2020"

established according to its definition of potentially observable characteristics. It is held on substantial definition, generally culturally meaning system having strong representation in some exclusions, such as music, some aspects of art and ritual and function possessing great adaptation value. Second, it is meaning creating unity of cultural form (constructive). Under this perspective, constructive rules argue that culture is creatable. Third, meaning becomes guidance for someone in performing certain aspects (directive). According this view, it is necessarily to stress on that learning meaning system will not automatically workable for learners and followers such rules unintentionally. Various elements of meaning system has determining trigger experienced by someone as it is required or obligation to perform something. For instance, if there is questionable event, someone may not indirectly answer it. However, due to normal condition, we will experience unbearable situation to provide answer. Lastly, meaning is certain emotional stimulator (evocative), particularly cultural meaning system is related to generative obligation and pressure as external sanction for any individual including conformity burden (obey and submissive) and social control as many have said or mandatorily exercised.

Based on above explanation, the research, therefore, is aimed to (1) identify and classify traditionally post-marriage ceremony of the Bolaang Mongondow ethnic; (2) recognize and categorize a unit of language, such as proverbs, prays, verses, word forms, phrases, clauses/sentences, discourses, and idioms, using during traditionally post-marriage ceremony of the Bolaang Mongondow ethnic; and (3) explain cultural meaning's components, as contained in verses, such as phrases, clauses/sentences, and idioms, during traditionally post-marriage ceremony in the Bolaang Mongondow ethnic.

\section{RESEARCH METHOD}

The research employed descriptively qualitative method. It is a method in analyzing status of a group of people, objects, events, or mindset system, or a class of present conditions. The objectives are to systematically, factually, and accurately describe, demonstrate, or portray facts, characteristics, and inter-phenomena relation being observed (Nazir, 2005).

In detail, data collection technique and equipment were derived from direct observation and recording, and document study (library research), regarding on relevant textbooks, result of seminary report, discourses, archives of traditional values and preservation center, and local library of North Sulawesi.

After relevant data was obtained, Anthro-Linguistic analysis was then utilized to scientifically review and investigate concerning on relation of ethnicity-based language and socio-cultural aspects. Data analyzed specifically was concept of vocabulary, phrase, clause/sentence, and discourse demonstrating components of cultural meaning. Later, it traced down relation of 
International Journal of Social Science and Economic Research

ISSN: 2455-8834

Volume:05, Issue:11 "November 2020"

language and traditionally post-marriage ceremony as the result of art and culture.

\section{FINDINGS AND DISCUSSION}

In this research, according to analysis performed, during traditionally post- marriage ceremony performed by the Bolaang Mongondow ethnic, there was local wisdom shown up through prudently wise words genealogically learnt as a guidance of life. Those wise words were in the form of vocabulary, phrase, clause or sentence, discourse, idiom stating special meaning related to its cultural meaning.

Particularly, identified and classified wise words demonstrating cultural meaning in traditional language of the Bolaang Mongondow were Gunung Ambang (Ambang Mount); gama 'mengambil' (taking out) bride heading into groom's house; polampangon kun tutugun lanang 'melangkah di depan pengantin wanita' (stepping in front of bride); pololanon kon tubig 'melewati air' (passing through water); poponikon kontukad 'menaiki tangga' (going up stairs); kungkum in pawung 'payung' (umbrella); pilat in siripu 'lepas alas kaki' (taking off shoes/sandals); polampa kon tonom 'melangkah di pintu utama' (stepping in the main door); pokilituan 'menyilakan duduk' (inviting to sit); pogapangan 'duduk berdampingan' (siting side by side); buka in kokudu 'buka penutup wajah' (opening the face lid); pokimamaan 'makan sirih dan pinang' (eating betel and areca nut); pongiobawan 'silakan makan' (inviting to dine); and polimumugan 'kumur-kumur' (gargle/rinsing the mouth).

In addition, following paragraphs comprehensively explain cultural meaning contained within traditionally post-marriage ceremony held by the Bolaang Mongondow.

Gama 'mengambil' (taking out) bride heading to groom's house and Ambang Mount. Ambang Mount is a mountain collated in the District of Bolaang Mongondow Timur. It has fascinatingly beautiful scenery, various type of plants, and tremendous natural preserve. This mount then was used as cultural symbol, meaning a virgin girl. The girl was represented as a fertile land providing descendant for sustainable life of a family. She also became entertainer for her family.

In the clause polampangon kon tutugan lanang 'melangkah dan melewati di depan pengantin wanita sampai titisan rumah' (stepping in and passing through front of bride until house's terrace), it had component of cultural meaning, which was begging to the God in order to wipe out all bad deeds of bride as she walks, like water dropping down in house's terrace.

Pololanon kon tubig 'melewati air' (passing through the water) literally meant water as purely washing and cleaning liquid. Its cultural meaning was that as passing through the water's channel, the God might enlighten the dark; if there was difficulty, the God might solve it; and, if 


\section{International Journal of Social Science and Economic Research}

ISSN: $2455-8834$

Volume:05, Issue:11 "November 2020"

there were dangerous goods, the God would wash it away through current flow of water, gone without trace forever. Additionally, passing through the water was reflection of expectation from new family in going through family's life. If there was obstacle, it would flow away by the water. Also, couples would pass their works with self-confidence, easiness, and obtaining good deeds.

Poponikon kon tukad 'menaiki tangga' (stepping up stairs) had referential meaning of stepping upward or going to higher place. This phrase had component of cultural meaning related to life cycle. Here, life was connected to career, blessing, and honor of both couples in passing through family's life. Those expectations from new family were aimed to be eternal step by step, similarly like stairs. Stepping up stairs was a symbol of family having brightly future life and target. While, stair was a symbol of achievement, target, life, and achievement.

Pumkum in pawung 'payung' (umbrella) had literal meaning as a tool used to prevent rainfall watering someone or avoid sunlight or sunbeam. In this case, umbrella was a cultural symbol to describe life's canopy. This canopy for couples' family represented as religion. They demanded peaceful life and it was considerably found in religion. Religion, thus, became their mindset in behaving and way of life. Subsequently, umbrella provided calmness and comfortability for them. They felt comfortable and secure by excitingly holding the umbrella tightly as a means of achieving life's goals and performing their family's objectives. In fact, umbrella, a means to protect from rainfall and sunlight, will provide peace during unwelcomed condition. Similarly, during traditionally post-marriage ceremony in the Bolaang Mongondow ethnic, it was symbolized as a way to bring family in achieving true concord.

Literally, pilat in siripu 'melepas alas kaki' was taking off shoes or sandals. The question was then why it had to take off shoes/sandals? The reasons were (a) health, due to bacteria or diseases; (b) respect, appreciating the host, surrounding, and others; (c) equality, demonstrating equal position with people inside the house. The bride was requested to take off her shoes/sandals while entering the groom's house. According to the Bolaang Mongondow's traditional language, the guhanga (term of traditional figure) said: anu buka'pa in siripmu oyuonka in barang moraat no $i$ tondoday ko i lampanganmu yo ta'padoman sia moruntut na'doman pinobukaan kon siripumu 'nak bukalah sendalmu' (take off your shoes/sandals, my child). Further, it denoted that if there were bad deeds along with bride's steps, all such bad deeds would go away with shoes/sandals taken off. Further, taking off shoes/sandals was taken as cultural symbol, describing that the bride entering the groom's house had become family and equal position in the groom's family.

Next, the meaning of polampa kon tonom 'melangkah di pintu utama' (stepping in the main 


\section{International Journal of Social Science and Economic Research}

ISSN: $2455-8834$

Volume:05, Issue:11 "November 2020"

door) was the bride had to enter the groom's house through the main door. While entering the house, the guhanga spoke in the Mongondow's language: "anu yo lampang don mangoy kon tonom sin iko de eman bidon ta'moko ki angoy sin ayin bidon nobali undam in yogang bo gogoy nami na'a kon bonu in baloy" 'nak melagkahlah di pintu utama karena engkau bukan lagi tamu, karena telah menjadi pengobat haus dan lapar di dalam rumah' (my child, please steeping inside the main door since you are no longer a guest, and you have become a cure of thirst and hungry in this house). This phrase became cultural symbol stating that the bride had officially become member of family. Typically, people have the main door in front of their house. There is no main door placed in the back of house. Additionally, the bride entering the groom's house carried fortunate for the groom's house.

Poilituan 'meyilakan duduk' (inviting to sit) depicted courtesy or manner for the guest to sit directly. Afterward, the guhanga uttered in the Mongondow's language: "anu yo litu'don iko sin singay naa iko nobali pabi lontu kon bonuin baloy" "nak duduklah kamu karena hari ini kamu telah menjadi yang di utama di dalam rumah' (my child, please sit since today you have become the spotlight of this house).

While, the phrase pogapangan 'duduk berdampingan' (sitting side by side) had referential meaning of sitting closely. This phrase was used as cultural symbol to depict that both had officially become legitimate couples. Their expectation then would not in despair and always closely attach, excluding there was mutual consensus. These couples had to maintain family's harmony in order not to easily provoke by anything. Jointly life together was articulated that newly marriage couples had to always closely live together in order to maintain communication, mutual trust and loyal, and reciprocal understanding and caring.

Buka in kokudu 'buka penutup wajah' connoted the bride requested to open her face lid. Then, in the Bolaang Mongondow's traditional language, the guhanga said: "anu aka motaaw yo pilatonpa in kokudumu'ba ontomgon pa nami in pogotmu 'nak kalau boleh bukalah penutup wajahmu agar kami bisa melihat wajahmu' (my child, please take off your face lid so that we can see your face). Moreover, the phrase of opening up face lid meant that there was no secret between them in the house since they were family.

In addition, the phrase pokimamaan 'makan sirih dan pinang' (eating betel and areca nut) articulated that as the bride sat, she was greeted with eating betel and areca nut as salute to her. It further said that the bride seemed a lovely flower decorating their house. Thus, chewing betel and areca nut, materials in welcoming guest, postulated cultural heritage. The guhanga presented betel and areca nut to chew as respect to honorable guest while submitting gifts (traditionally known as seserahan), and he spoke in the Mongondow's language: anu naa in pomama pa awu 


\section{International Journal of Social Science and Economic Research}

ISSN: $2455-8834$

Volume:05, Issue:11 "November 2020"

iko sin ba umurpa moroton in badan mu,morotonpa jiwa mu bo morota in pikiranmu 'nak ini tempat sirih dan makanlah siri dan pinang agar badan selalu sehat' (my child, it is the box of betel and eat this betel and areca nut for your health). The phrase of eating betel and areca nut functioned as strengthening teeth, healing wound in the mouth, and eliminating smelling breath. It was used as cultural symbol to articulate strengthening relationship between the bride and groom, brother and sister, father and mother, and all members of the house to be happily big family. A well-arranged and firm teeth represented strong and eternal family relationship. Meanwhile, eating betel and areca nut, functioned as healing wound and eliminating smelling breath, culturally symbolized avoiding bad events.

From the phrase pangiobawan 'silakan makan' (inviting to dine), the guhanga served dishes already available to the bride while giving gifts (or, seserahan) and spoke in the Mongondow: anu pogiobawpa sin noyayu in bi nayaanmu 'nak makanlah karena kamu berjalan jauh' (my child, eat it as you have long journey). Then, it was continued with spoon-feeding daughters and both brides were mutually spoon-feeding. The phrase spoken by the guhanga became cultural symbol describing that their family journey was lengthy.

Finally, the phrase polimumungan 'kumur-kumur' (gargle/rinsing the mouth) was shown as mother, a family representative, presented water as cultural sign for the bride to gargle in order to rinse the rest of food, while the guhanga said in the Mongondow's language: anu yo molimumugdon iko sin bagu nopalut nogiobaw poigumun konbarakat i togi kehendak yo jiwa bopikiranmu umur pa ta'salalu mo darit bo mo sehat 'nak berkumurlah karena engkau baru selesai makan dan memohon berkah kepada Tuhan agar pikiranmu selalu bersih dan sehat (my child, rinse your teeth as you has finished eating and beg for the God's blessings, so that your mind is clear and vigorous)

\section{CONCLUSION}

Based on above findings, this research demonstrates that there were 13 steps during traditionally post-marriage ceremony in the Bolaang Mongondow ethnic, namely: (1) Gama 'mengambil' (taking out) the bride heading to the groom's house; (2) Polampangon kon tutugan lanang 'melangkah di depan pengantin wanita sampai di bawah tirisan rumah memohon berkah kepada Tuhan kalau ada keburukan bersama langkahmu maka akan meresap seperti air yang jatuh ditirisan rumah' (stepping in and passing through front of bride until house's terrace); (3) Pololanon kon tubig 'melewati air' pengantin wanita melewati saluran air sambil memohon kalau ada yang gelap maka akan diterangkan, yang runcing di tumpulkan, barang tajam terbawa arus air sampai hilang lenyap tak berbekas (as the bride passed through the water's channel, she begged to the God to enlighten the dark; if there was difficulty, the God might solve it; and, if 


\section{International Journal of Social Science and Economic Research}

ISSN: $2455-8834$

Volume:05, Issue:11 "November 2020"

there were dangerous goods, the God would wash it away through current flow of water, gone without trace forever); (4) Poponikon kon tukad 'menaiki tangga' rumah ini rumah mu juga jangan ragu-ragu karena engkau telah di jumput dengan adat ,bahasa dan aturan sambil memohon berkah dari tuhan rizeki kalian berdua berlipat ganda' (stepping up stairs, this house is your house, do not hesitant as you has been taken by custom, language and rules while begging the God's blessings to double couples' blesses); (5) Kungkum in pawung 'payung' (umbrella); (6) Pilat in Siripu 'lepas alas kaki' (ordered to take off shoes/sandals so that bad deeds along with her steps will wipe away); (7) Polampa kontonom 'melangkah di pintu utama' melangkahlah di pintu utama karena engkau bukan lagi tamu ,karena telah menjadi pengobat haus dan lapar di dalam rumah' (please steeping inside the main door since you are no longer a guest, and you have become a cure of thirst and hungry in this house); (8) Pokilituan 'mempersilahkan duduk' (ordered to take a sit since the bride has become the spotlight in the house today ); (9) Pogapangan 'duduk berdampingan', the bride had become the main and closely bound relation of one with other in the house; (10) Buka 'in kokudu 'membuka penutup wajah', in order to see the bride's face; (11) Pokimamaan 'makan sirih dan pinang' betel made healthy body'; (12) Pongiobawan 'silakan makan' it was followed by mutually spoon-feeding between the bride and the groom, and the parents also; and (13) Polimumugan 'kumur-kumur' gargling/rinsing the mouth to make healthy and clear mind.

\section{REFERENCES}

D'andarde, R.G. Culture Theory, Essay on Mind, Self and Emotion. Editor Richard,A. Schweder and Robert, A. Levine. London University.

Djajasudarma, F. 1977. Nilai Budaya dalam Ungkapan dan Peribahasa Sunda. Jakarta: Pusat Pembinaan dan Pengembangan Bahasa. Departemen Pendidikan dan Kebudayaan.

Djawanai, S. 2011. Sumbangan Etnolinguistik Bagi Kemanusiaan.Makalah: disajikan pada Program Pascasarjana Bidang Etnolinguistik, Universitas Sam Ratulangi Manado.

Eilers, F. J. 1995. Berkomunikasi Antara Budaya. Terj. J. Tondowidjojo. Ende: Nusah Indah.

Koentjaraningrat . 2005. Pengantar Ilmu Antropologi. Jakarta: Bhineka Cipta Lumempouw, F. 2018. Penggunaan Bahasa Dalam Proses Upacara Adat Perkawinan

Etnik Bolaang Mongondow. Hasil Penelitian: Lembaga Penelitian dan Pengabdian Kepada Masyarakat Universitas Sam Ratulangi

Mamita, R. dan Oktavianus. 2008. Perilaku Berbahasa Masyarakat Minangkabau dan 
International Journal of Social Science and Economic Research

ISSN: 2455-8834

Volume:05, Issue:11 "November 2020"

Pengaruhnya Terhadap Pemakaian Ungkapan Sebagai Media Pendidikan Informal Keluarga. Linguistik Indonesia. Jurnal Ilmiah MLI. Jakarta. No. 2. Tahun ke -26.

Panggabean, M. Ed. 1981. Bahasa Pengaruh dan Peranannya. Jakarta: PT Gramedia. Robins, R. W. 1992. Pengantar Linguistik. Jakarta: ILDEP.

Saussure, F. 1988. Pengantar Linguistik Umum. Edisi Ind. Yogyakarta: Gajah Mada University Press.

Sapir, E. 1921. Language: An Introduction to the Study of Speech. New York: Harcourt, Brace and Company. 